\title{
Foreword by the Editors
}

Due to the rise of Nazism, the German invasion of Poland in September 1939 and the subsequent occupation of other countries by the Wehrmacht, large parts of Europe found themselves in a difficult political, economic and military situation. At the same time, as both occupying force and Axis partner, the Nazis were establishing governments that would cooperate with them. In many of these countries, war crimes and genocidal policies against various minorities within the country were intentional, most often in the course of their own territorial pursuits. Against the background of the war, European countries and societies reacted with a mixture of passivity, fatalism, collaboration but also resistance. Yet what did this situation mean for public life, the prospects of the particular country and for the existentially endangered groups and individuals? Which forces actively collaborated with the occupiers and tried to turn this to their own advantage?

Collaboration, also referred to as collaborationism in professional circles, is today considered to be one of the most problematic aspects of the history of occupation in World War II as well as of the Holocaust. In this context, the starting points, motivations, behaviors, reactions and actions taken by political systems, institutions, groups and individuals varied widely and depended on diverse factors and the dynamics of events determined by the war and filled with violence.

Viewing the different forms all over Europe of collaboration with Nazi Germany is less complicated due to the fact that only instances of resistance - real or imagined - against the former dominance of Germany are subject to debate. This generally politicized narrative was cultivated especially in the post-war period to strengthen the sense of community and national identity in the Eastern Bloc countries, but also in France and Italy. At least in some European countries, a more revisionist presentation of the phenomenon of collaboration and the significance it had in World War II has come to prevail. Narratives about the country's own victims and losses compete with memories of those minorities and objects of hate, including Jews, Sinti and Roma, who were left completely defenseless and at the mercy of the German occupying forces, their allies and collaborators.

In May 2019 in Rome, the conference "Collaborationism with Nazi Germany. A European Controversy”, organized by the Moses Mendelssohn Center for European-Jewish Studies in Potsdam and the La Sapienza University in Rome, was dedicated to this topic, analytically comprehensive yet regionally specific. It brought researchers and academics from many different countries together, who from their different perspectives reflected on the similarities and differences in European collaboration with Nazi Germany. Some of the contributions published in this volume are based on lectures given at this conference. Additional 
contributions and country analyses have been added to provide a more precise view of this phenomenon and to round off the volume.

The present volume does not claim to be complete. This book cannot and does not intend to be. What is presented here is an attempt at taking stock to describe and evaluate the behavior of some countries in World War II. Moreover, this book seeks to stimulate further studies and academic and social discussions about collaboration, particularly in those countries where the country's collaboration with the Nazis is ignored, unmentioned or taboo.

\section{Research, Terminology and Theoretical Approaches}

Since the 1970s, people have begun to consider collaboration a subject for research, especially in Western Europe. ${ }^{1}$ Meanwhile, this wide-ranging topic which still includes some "blind spots" - has become an established field of research. ${ }^{2}$ There are now a large number of works with country-specific studies on collaboration, ${ }^{3}$ which deal in particular with the trans-national participation in the organized mass murder of European Jews. ${ }^{4}$ Some of these works are dedicated to the cooperation of the military with the German Wehrmacht on its campaigns of conquest; ${ }^{5}$ others examine economic relations with Nazi

1 For more on this see: Werner Röhr, ed., Europa unterm Hakenkreuz. Okkupation und Kollaboration, 1938-1945 (Berlin/Heidelberg: Hüthig, 1994), 17-30.

2 For more on this see: Grzegorz Rossoliński-Liebe, "Kollaboration im Zweiten Weltkrieg und im Holocaust. Ein analytisches Konzept,” Docupedia-Zeitgeschichte, 19.07.2019, accessed August 27, 2020, https://docupedia.de/zg/Rossolinski-Liebe_kollaboration_v1_de_2019, 1-32.

3 Cf. this volume's bibliography organized by country and the comprehensive overviews by Peter Black, Béla Rásky and Marianne Windsperger, eds., Collaboration in Eastern Europe during the Second World War and the Holocaust (Vienna/Hamburg: New Academic Press, 2019); Klaus Kellmann, Dimensionen der Mittäterschaft. Die europäische Kollaboration mit dem Dritten Reich (Vienna/Colongne/Weimar: Böhlau Verlag, 2019); István Deák, Europe on Trial. The Story of Collaboration, Resistance, and Retribution during World War II (Boulder: Westview Press, 2015); Joachim Tauber, ed. "Kollaboration" in Nordosteuropa. Erscheinungsformen und Deutungen im 20. Jahrhundert (Wiesbaden: Harrassowitz Verlag, 2006); Christoph Dieckmann, Babette Qiunkert and Tatjana Tönsmeyer, eds. Kooperation und Verbrechen. Formen der "Kollaboration" im östlichen Europa 1939-1945 (Göttingen: Wallstein Verlag, 2003); Werner Röhr, ed., Europa unterm Hakenkreuz. Okkupation und Kollaboration, 1938-1945 (Berlin/Heidelberg: Hüthig, 1994).

4 Raul Hilberg, The Destruction of the European Jews (New Haven: Yale University Press, 2003); Saul Friedländer, Nazi Germany and the Jews, 1933-1945. 2 vol. (New York: Harper Perennial 1998/2008).

5 See f. e. Jochen Böhler and Robert Gerwarth, eds., The Waffen-SS. A European History (New York/Oxford: Oxford University Press, 2017); Rolf-Dieter Müller, An der Seite der Wehrmacht. 
Germany. ${ }^{6}$ Even specific professions that shaped the particular societies have become subject to academic research, i.e. the collaboration of intellectuals ${ }^{7}$ or moviemakers. ${ }^{8}$ Studies on the so-called "sentimental" collaboration, especially in France and Italy ${ }^{9}$ along with the actions of Fascist and nationalistic women ${ }^{10}$ also include gender-specific questions and problems. The forced collaboration of the Judenräte, the Jewish police and the so-called "Greifer" with the Nazis ${ }^{11}$ has also increasingly come into the focus of research. It has also been the subject of memoirs and novels. ${ }^{12}$ Movies $^{13}$ have been made showing the phenomenon of

Hitlers ausländische Helfer beim “Kreuzzug gegen den Bolschewismus” 1941-1945 (Berlin: Ch. Links Verlag, 2007).

6 See f. e. Dietrich Eichholtz, "Wirtschaftskollaboration und 'Ostgesellschaften' in NS-besetzten Ländern (1941-1944)" in Okkupation und Kollaboration in Europa unterm Hakenkreuz. Okkupation und Kollaboration (1938-1945), ed. Werner Röhr (Berlin/Heidelberg: Hüthig, 1994), 433-459; Richard J. Overy, ed., Die “Neuordnung” Europas: NS-Wirtschaftspolitik in den besetzten Gebieten (Berlin: Metropol, 1997).

7 Maria Björkman, Patrik Lundell and Sven Widmalm, eds., Intellectual Collaboration with the Third Reich. Treason or Reason? (London/New York: Routeledge, 2019).

8 Roel Vande Winkel and David Welch, eds., Cinema and the Swastika: The International Expansion of the Third Reich Cinema (Basingstoke: Palgrave Macmillan, 2007); Markus Spieker, Hollywood unterm Hackenkreuz: der amerikanische Spielfilm im Dritten Reich (Trier: WVT Wissenschaftlicher Verlag, 1999).

9 This is also known as "horizontal collaboration". Cf. Fabrice Virgili, Shorn Women: Gender and Punishment in Liberation France (Oxford: Berg, 2002); Nicoletta Moccia, Il male commune nella storia. Le donne collaborazioniste processate a Milano dal 1954 al 1947 (Milan/Udine: Mimesis, 2019). Compare to the study on women in Poland: Maren Röger, Kriegsbeziehungen: Intimität, Gewalt und Prostitution im besetzten Polen 1939 bis 1945 (Frankfurt/Main: Fischer, 2015).

10 Cf. the new studies on female Fascists in Eastern and South-Eastern Europe Andrea Petö, Láthatatlan elkövetők - Nők a magyarországi nyilas mozgalomban (Budapest: Jaffa Kiadó, 2019); Olena Petrenko, Unter Männern. Frauen im ukrainischen nationalistischen Untergrund 1944-1954 (Paderborn et al.: Ferdinand Schöningh, 2018), and Martina Bitunjac, Verwicklung. Beteiligung. Unrecht. Frauen und die Ustaša-Bewegung (Berlin: Duncker\&Humblot, 2018).

11 Cf. Isaiah Trunk, Judenrat. The Jewish Councils in Eastern Europe under Nazi Occupation (New York: University of Nebraska Press, 1972) and Julius H. Schoeps, "Die Zusammenarbeit der Judenräte mit den NS-Behörden im historisch-kritischen Urteil der Nachwelt,” in Jewish Lifeworlds and Jewish Thought: Festschrift Presented to Karl E. Grözinger on the Occasion of his $70^{\text {th }}$ Birthday, ed. Nathanael Riemer (Wiesbaden: Harrassowitz Verlag, 2012), 343-348.

12 Cf. f. e. Léon Werth, 33 Days. A Memoir, introduction by Antoine de Saint-Exupéry (New York: Melville House, 2015) and Irène Némirovsky, Suite française (Paris: Gallimard, 2006).

13 Over recent years, there have been several movies released dealing with this topic: at the beginning of the German-Russian Holocaust film "Paradies" (2016) by Andrej Kontschalowski, collaboration by French security forces is discussed. The German three-part tv movie "Unsere Mütter, unsere Väter" (2013) from the director Philipp Kadelbach deals with anti-Semitism in the Polish resistance movement and among collaborating Poles, which caused controversial headlines not 
collaboration to a wide audience. All of this makes it clear that collaboration and resistance are topics that play an increasing role in the discourses of memory. ${ }^{14}$

Despite the interdisciplinary research and medial reflections that are already available, no satisfactory uniform definition of the phenomenon of "collaboration" exists, primarily due to the complexity and variability of the term. Co-working, cooperation, collusion, complicity, betrayal - historiography has used various terms to make the topic of collaboration both tangible and understandable. It is, however, clear that these terms are insufficient, some of them even problematic. This is especially true for the alternative use of the word "cooperation", a word which implicitly suggests working together with the occupiers as equals. ${ }^{15}$

The interpretation of the term is further complicated by the fact that the historical perception and interpretation of collaboration varies widely: Resistance fighters and political opponents of the Nazi regime considered all forms of working together with the German occupying forces, even if it was the result of the unequal power structure, as treason. From the politician to the businessman, the worker to the simple domestic servant, the anti-Fascist resistance considered all those who worked for the Germans to be their supporters and thus traitors. The Soviets even considered forced laborers, who were forced to work under inhumane conditions in Nazi Germany, to be collaborators. After their liberation and return home, they were often killed or imprisoned. In this light, what we understand by "collaboration" is an extremely elastic and often morally charged term.

In fact, a broader definition of "collaboration" includes a wide range of coworking between politicians, the military, representatives of business, culture and other professions. The term leaves the exact motive - coercion, persuasion, adaption or pragmatism - just as undefined as Germany's various forms of political domination in the occupied or allied countries. Despite this and other concerns, the word "collaboration" has become established as a catch-all for the various forms of the asymmetrical cooperation with the Nazis - even during

only in Poland. The Hollywood movie "Defiance" (2008) telling the true story of the Bielski Partisans, Jewish resistance fighters, and shows the collaboration of Belarusian police.

14 John-Paul Himka and Joanna B. Michlic, eds., Bringing the Dark Past to Light: the Reception of Holocaust in Postcommunist Europe (Lincoln: University of Nebraska Press 2013); Harald Welzer, ed. Der Krieg der Erinnerung: Holocaust, Kollaboration und Widerstand im europäischen Gedächtnis (Frankfurt/Main: Fischer, 2007).

15 Cf. Rossoliński-Liebe, "Kollaboration im Zweiten Weltkrieg und im Holocaust. Ein analytisches Konzept," 2. 
World War II. There are no alternative suggestions of what to call this phenomenon or are rarely if ever considered. ${ }^{16}$

In the present volume, we define collaboration as a part of the history of World War II, the history of occupation and everyday life and as an essential influencing factor in the Holocaust. Collaboration is understood to be a reaction to offerings and (forced) demands made by the Nazis that legitimized, accompanied, exercised, supported and/or made the Nazi policies possible. However, the term, understood as a catch-all term, cannot provide a clear separation of the conditions and circumstances under which this happened. ${ }^{17}$ In the academic debate on this topic, which should be interdisciplinary and conducted from an international perspective, the analysis of spheres of influence and room for maneuver of the respective governments, institutions and people is of primary importance.

\section{Dimensions of Collaboration}

Collaboration took place in every country in Europe which was occupied by or allied with Nazi Germany or which were neutral. Its variety of forms and expressions encompassed all social groups, political parties and organizations, economic and cultural sectors, the church and the military along with the authorities and the police. However, an examination of this spectrum must take into account the various methods of Nazi rule, such as military and civil administration. The Nazis were the ones who dictated how the political collaboration would proceed with each country.

Although the Germans pursued an ideologically based and economically motivated policy throughout Europe, unlike in Western Europe, the "new masters" exercised a more aggressive use of power of "domination, administration and exploitation" in the East. Three of their main goals of occupation were the territorial expansion of Lebensraum, the exploitation of the respective country's human and material resources and the annihilation of undesirable populations: the Slavic so-called "subhumans", the Jews, Roma, homosexuals, the sick, Free Masons and the politically unreliable. ${ }^{18}$

16 Cf. Kellmann, Dimensionen der Mittäterschaft, 12.

17 Cf. Röhr, Okkupation und Kollaboration in Europa unterm Hakenkreuz, 63, 84.

18 Hagen Fleischer, "Nationalsozialistische Besatzungsherrschaft im Vergleich: Versuch einer Synopse," in Anpassung. Kollaboration. Widerstand. Kollektive Reaktionen auf die Okkupation, eds. Wolfgang Benz, Johannes Houwink ten Cate and Gerhard Otto (Berlin: Metropol Verlag, 1996), 257-302, here $271 \mathrm{f}$. 
All key positions in public life were placed under German control, so that self-administration by locals was only possible at the lowest levels, as Stephan Lehnstaedt and Joachim Tauber illustrate in the present volume in the countries of Poland and Lithuania. The persecution policy carried out by the German occupiers in Eastern Europe included the use of mass terror. Resistance in particular was met with retaliation and harsh sanctions against the civilian population. For example, in the Czech town of Lidice after the assassination of Reinhard Heydrich, the director of the Reich Main Security Office and Deputy Protector of Bohemia and Moravia, or in the Serbian towns of Kragujevac and Kraljevo, where more than 4,000 civilians were killed by the Wehrmacht in October $1941 .^{19}$

In contrast to the rigid policy of exploitation and violence seen in Eastern Europe, the German occupying forces were more "moderate" in Western Europe. Unlike in the East, in the Netherlands or in Scandinavia, for example, a national administration was re-established under German control. The population in Norway, for example, experienced better treatment overall by the Nazi occupying forces, as the local population was considered to be "racially" more valuable than the Slavs. In addition, the occupying force profited from the existence of and committed cooperation from Nazi or Fascist political groups, parties or sympathizers which existed in every country and who seized this opportunity to establish themselves in power politics. ${ }^{20}$

Nevertheless, the willingness to cooperate with the Germans depended on various factors, such as how the new rulers treated the civilian population and what the local pre-existing historical enemy stereotypes were, determined by previous wars (with the exceptions of Denmark, Norway and the Netherlands). Other influencing factors included the moment of surprise at the unexpected German invasion and the subsequent defeat of the respective country, as it was, for instance in Poland and Yugoslavia, but also in the Netherlands, Denmark and Norway. ${ }^{21}$ In countries like Slovakia, collaboration was seen as a guarantee for the creation and continued existence of their own state under German influence. In addition, some countries profited from their own territorial ambitions being

19 Cf. Lukia Drulia, ed., Von Lidice bis Kalavryta: Widerstand und Besatzungsterror. Studien zur Repressalienpraxis im Zweiten Weltkrieg (Berlin: Metropol Verlag, 1999) and Oliver von Wrochem, ed., Repressalien und Terror. "Vergeltungsaktionen" im deutsch besetzten Europa 1939-1945 (Leiden/Boston: Brill, 2017).

20 Cf. Arndt Bauerkämper and Grzegorz Rossoliński-Liebe, eds., Fascism without Borders: Transnational Connections and Cooperation between Movements and Regimes in Europe from 1918 to 1945 (New York: Berghahn, 2017).

21 Fleischer, "Nationalsozialistische Besatzungsherrschaft im Vergleich: Versuch einer Synopse," $262 \mathrm{f}$. 
approved of by Nazi Germany. Countries which collaborated politically also had enough room to maneuver to avoid German demands regarding the deportation of the Jews and other areas of collaboration, particularly when their own national interests were at stake.

The behavior of each local population should be seen in relation to the actions of their governments. The line between voluntary and forced collaboration was often very thin. Some people became involved out of necessity, they collaborated for fear of deportation and reprisals; others did so for the opportunities for personal advancement, an improvement in living conditions, pragmatism, corruption, personal gain or ideological conviction. Alternatively, they remained passive, went about their daily lives as usual and thus supported the criminal activities in their country with their indifference. It can be assumed that without the aid and abettance of the local authorities and the conformist behavior of the local population, the German occupying machinery could not have functioned as it ultimately did.

The most tragic effects of collaboration were seen in the persecution and murder of six million Jews and those classified as Jews. Anti-Semitism in all its manifestations was prevalent all throughout Europe; it was present in all social classes and now underwent a political and criminal radicalization. Collaboration with the Germans fell on ears already fertile with anti-Semitism, which, in some countries had already been enshrined into law before the German occupation, like in Hungary (in 1920) and in Yugoslavia (in 1940). In allied and cooperative countries, discussions about the execution of the persecution measures dealt only with formalities and the division of tasks to complete the deportation. There were, however, also regimes, such as the Croatian Ustaša, which also acted autonomously in the extermination of Jews. They did not require instructions; they acted on their own initiative accordingly.

\section{About this Book and its Topics}

Most of the contributions in this volume range between country-specific overviews and micro-historical studies. The present volume will try to show facets of the complexity of the history of collaboration from different perspectives. These facets range between decisions of state and reactions to Nazi proposals, national and economic interests, country-specific aspirations of hegemony, pragmatic decisions and Nazi pressure.

The local cooperation and assistance with Nazi Germany in the handing and implementation of the Holocaust takes a central place in this book, especially since the "extermination" of the entire Jewish population was an expressly stated 
goal of the Nazis. In order to carry this out, special Judenberater (Jewish advisors) were made available to some countries. Anti-Jewish laws formed the basis for discrimination and deportation. In addition, military units and local police forces were set up to implement the deportation and annihilation of the Jews. Moreover, there was an enormous level of participation from governments, political players and "normal" people in the process of exterminating the Jews and in receiving expropriated Jewish property, motivated by anti-Semitism and other factors. The clarification of this European readiness to contribute to the Holocaust, which played into the Germans' hands, has in retrospect led to the demythification of the still widespread perception of German sole responsibility and/or guilt.

The fact that this guilt does not correspond to the historical overview of collaboration is already made clear in the first chapter of the present volume "Western Countries between Collaboration, Neutrality and Resistance”, in which Lars Dencik describes and analyzes the various forms of collaboration in the Scandinavian countries. Valentina Sommella concentrates on the political-military collaboration of the Vichy regime and the French involvement in the persecution of the Jews, highlighting the interaction between Generals Pétain and de Gaulle, who divided the country into those who collaborated and those who took up armed resistance against the German occupying forces.

In the second chapter "Aspects of Collaboration in Central Europe: The Cases of Poland and Hungary", in his country study of occupied Poland, Stephan Lehnstaedt focuses on the political and administrative collaboration along with the (military) cooperation of ethnic Germans, while Alessandro Vagnini illustrates German-Hungarian relations primarily on the basis of the anti-Semitism already pervasive and enshrined by law in Hungary before the German invasion in March 1944.

In the chapter "Countries of Eastern Europe: Political Interests, Anti-Semitism and Military Support”, Olaf Glöckner's overview of the situation reveals some facets of Ukrainian collaboration in the military involvement in the war against the Soviet army and the murder of the Jews through mass violence. Giuseppe Motta focuses on political, economic and ideological anti-Semitic collaboration in the case of Romania. In his country analysis of Lithuania, Joachim Tauber concentrates particularly on the political-administrative level, taking into account the ghettos in Vilnius, Kaunas and Šiauliai run by local authorities and their participation in the Holocaust.

In the chapter "Collaboration in Slavic and Balkan Countries", Martina Bitunjac illustrates the persecution and murder of the Jews in the Slovak State and the Independent State of Croatia, both of which cooperated with Nazi Germany. Björn Opfer-Klinger analyzes different political aspects (i.e. diplomacy, the economy) of the Bulgarian collaboration with the Third Reich, both before 
and during the war, while Meinolf Arens and Katerina Kakasheva deal with two special regions of the Balkans, occupied Vardar Macedonia and West Banat scenes of German, Bulgarian and local terror with particularly aggressive persecution of the Jews and mass violence.

The following chapter "South European Case Studies: Greece, Italy and Portugal” begins with Ioannis Zelepos' examination of Greek military formations, the security battalions, within the framework of German occupation politics. In her micro-historical study, Ester Capuzzo illuminates the effects of the Italian "racial laws" on the Jewish community in Fiume (Rijeka) on the territory of what is now Croatia, which fought to survive the at times collaborating, at times competing Italian, German and Croatian forces. Fernando Clara demonstrates that collaboration also encompassed the cultural sphere in neutral European countries, using the example of the various ways the Portuguese Secretariat of National Propaganda in the Estado Novo had room to maneuver.

In the final chapter "Reflections on Jewish 'Cooperation' with the Nazis in Western and Eastern Europe”, Julius H. Schoeps devotes himself to the forced cooperation of the Judenräten (Jewish Councils) and individual Jewish informers, the so-called Greifer, who were fighting to survive and after World War II found themselves confronted with accusations of having betrayed their fellow Jews, thereby making themselves culpable.

The present volume is thus intended as a contribution to the still current and in many countries emotionally charged debate about the motivations, forms and possible leeway in collaboration with the Nazis. This is particularly true in the chapters dealing with how collaboration was treated in Germany, France and the countries of the former Yugoslavia, in Ukraine and Hungary in the context of today, illustrating the associated problems of a differentiated historical treatment and an adequate memory culture.

New forms of right-wing populism, nationalism and growing intolerance of Jewish fellow citizens and minorities have made such historically sensitive studies considerably more difficult in many countries today. Instead, Fascist holidays are being celebrated and war criminals are enjoying growing popularity in some places. Contradictory memories of Nazism, Fascism, occupation and the Holocaust collide. The discussion about what was then right and wrong, about victims and perpetrators is at times emotionally charged and, particularly in post-Communist Eastern Europe, accompanied by a political polarization.

Against this background, a further goal was to shed light the current political and social perceptions of collaboration and collusion, which had been taboo in many countries after the war. Krisztián Ungváry criticizes and analyzes the myth of only the Germans being responsible for the crimes of World War II and the Holocaust, which has recently been cultivated even by official German foreign policy. 
Serge Klarsfeld distances himself from mythologizing publications about World War II in France and - from the perspective of a Holocaust survivor - makes Vichy France's complicity in the Holocaust clear. Trvtko Jakovina examines the distorted historiography in the countries of the former Yugoslavia, particularly in Croatia and Serbia, where collaboration is still partially a taboo and unmentionable. Franz Sz. Horváth and Imre Szakál critically examine the partially revisionary memory politics in Hungary and Ukraine, respectively.

For making the conference at the La Sapienza University possible, we would like to thank our friends and colleagues in Rome: Giovanna Motta, Antonello F. Biagini, Alessandro Saggioro, Giuseppe Motta and Roberto Sciarrone. We would like to thank Elke-Vera Kotowski from the Moses Mendelssohn Center in Potsdam for revealing a humane aspect of World War II, which she presented in the exhibit "Rescuers, Helpers, Unsung Heroes. Rescue Resistance during the Nazi Period in Europe" in cooperation with the Jewish community of Rome at the Italian Institute for German Studies as part of our conference. Many thanks go to Margaret-Ann Schellenberg for the thorough editing and translation of some contributions and essays. We also owe our thanks to the librarians of the Moses Mendelssohn Center, Karin Bürger and Ursula Wallmeier, as well as Felix Lohmann for their help in the preparation of the extensive bibliography. We thank Andreas Toscano del Banner for creating the maps published here. Finally, we would like to thank all of the authors who have enriched this book with their scholarship and sociocritical analyses.

To commemorate the victims of the Holocaust, who were at the mercy of a systematic policy of extermination, in times of resurging anti-Semitism, we have selected a photograph showing a Jewish man whose beard is being forcibly removed by young members of the Hlinka Guard in the Slovak town of Stropkov for our cover. According to the Yad Vashem Archives, this shows Lipe Baum, owner of a large farm. Amused and laughing, these members of the paramilitary defense organization of the Slovak government posed for several pictures with their deliberately chosen Jewish victims. The main focus of the photos is not, however, the five perpetrators as intended, but rather the Jewish man who is looking directly at the camera. Lipe Baum had to suffer the violence, but they could not take away his dignity. The photo was taken shortly before the Jewish man, his family and the Jewish residents of his town were deported. He was later murdered in the German extermination camp Sobibór. ${ }^{22}$

22 Cf. the information about Lipe (Leib) Baum in the Central Database of Shoah Victim's Names in the Yad Vashem Archives, Jerusalem, accessed August 18, 2020, https://yvng.yadva shem.org/index.html?language $=$ en\&s_lastName=Baum\&s_firstName $=$ Lipe\&s_place $=\& s \_d a$ teOfBirth=\&cluster=true. 
Public humiliation, dehumanization, intimidation and the public display of Jews were seen on the streets every day in the 1930s and 1940s - whether in Germany, Austria, Poland, Belarus, Ukraine or Lithuania. The discrimination ranged from the humiliating cleaning of sidewalks, Jews being made to hang a sign with anti-Semitic content around their necks, the removal and burning of sidelocks and beards of Orthodox Jews to the public undressing of Jewish men and women and brutal lynchings on public squares (particularly in Eastern Europe). The victims were defenseless, completely at the mercy of the initiators of the violence, the spectators and onlookers. The photographic recording of these cruelties represented an additional violation; it was part of the crime and was to serve the perpetrators as proof of a successful demonstration of power over the exterminated Jewish population.

Today these photos are not only historical testimonies of European antiSemitism and the Holocaust, which - as this book shows - was greatly facilitated by the close collaboration between Nazi Germany and other European countries. They also serve as a timeless wake-up call and admonition against anti-Semitism, Holocaust relativism, hate and racism - phenomena that no society, then or now, was or is immune to.

Martina Bitunjac and Julius H. Schoeps Potsdam 2020 
